\title{
Local Wisdom in Traditional Game Kasti as Cultural Values of Character Building
}

\author{
H Susilo', Salliyanti ${ }^{2}$ \\ \{1 hariadisusilo722@gmail.com, ${ }^{2}$ salliyanti@gmail.co.id \} \\ ${ }^{1,2}$ Universitas Sumatera Utara, Medan, Indonesia
}

\begin{abstract}
Local wisdom in traditional game, kasti (a ballgame played between two teams of 12 players each) as cultural values integrates character building. The research used qualitative method. Descriptive qualitative data consisted of primary and secondary data. Primary data were gathered by observing, recording, documenting, and analyzing the data from the presentation of the traditional game. Secondary data were the information obtained from various sources such as books, documents, photographs, theses, dissertation, internet, research report, articles, and the other writings which contained knowledge, dealing with the subject matter of the research. The result of the research showed that the values of character building which dominantly establish traditional game, kasti were a) creativity, b) religiosity, c) curiosity, d) discipline, e) democracy, f) hard working, g) tolerance, h) responsibility, i) achievement, and j) appreciation.
\end{abstract}

Keywords: Local Wisdom, Cultural Values, Method, Finding

\section{INTRODUCTION}

The term, local wisdom, consists of two words, wisdom and local. The word, 'wisdom' means the ability to think and act using knowledge, experience, understanding, and common sense, and 'local' means limited to a particular part of an area (local area). Therefore, local wisdom can be understood as ideas and knowledge in a local area. Wisdom has good and moral values; it is used as guidance for community members who come from a certain culture as the entity and from a culture geographically [1]. In general, local wisdom can be interpreted as local ideas that are wise, full of wisdom, good value, which is embedded and followed by members of the community. In the discipline of Anthropology local wisdom known by the term local genius [2].

Local wisdom is indigenous wisdom or knowledge of a certain community; it comes from the traditional culture from generation to generation, and it is used to organize people's life structure. Since it is focused on cultural values, it can be defined as follows: Local wisdom is local cultural values which can be used to organize people's life structure wisely and prudently. The first definition emphasizes more on local wisdom to organize social structure which comes from glorious and sublime cultural values, while the second definition emphasizes on sublime cultural values to organizes social structure [3]. Furthermore, local knowledge is a personality, cultural identity of the community in the form of values, norms, ethics, beliefs, customs, and special rules accepted by society and proven ability to survive continuously [4].

Traditional knowledge is the knowledge which is owned or controlled from generation to generation and is still developed according to the exchange in environment. Bishop, et. al. in his 
journal [5] point out that traditional game is "...a game which has been handed down from generation to generation; it has good, positive, valuable, and desirable values. Local wisdom can be understood as human attempt to use his common sense (cognition) to act and to behave toward something, object, or event which occurs in a certain space. This understanding is arranged etymologically in which wisdom can be understood as one's capacity, using his reasoning, to act or behave according to his evaluation on an object of an event.

Traditional game, kasti as a local wisdom is one of the efforts to develop children to have proper behavior by instilling cultural values in character building through various activities. From these various activities, consciously or unconsciously, a traditional game contains integrated character values which are beneficial in instilling good character values in children [6].

A traditional game is a game which contains good cultural values and has its function to train its players to do important things which will be very beneficial for their social life in the future; for examples, training them to calculate, to think aptly and wisely, not to be overly sentimental, to be courageous, to be honest, to be sportsmanlike, etc. The values of environmental wisdom are abstractions of people's experiences of adapting to their environment in a broad sense, and can be considered as guidelines, ways and directions for the most effective activities for the supporting community in carrying out community life in their environment [7]-[9]. In addition, this kind of information could enable physical education teachers to help students develop the attitudes, behaviors, and cognitive strategies required to become "healthy and competent" overall - that is, socially, emotionally, academically, and physically, because these four domains are closely related to one another. This information would increase people's emotional awareness, something key to developing social skills [10].

As the time passes and technology is developing rapidly, children are easily influence by this globalization and the advancement of technology. They begin to abandon traditional games and prefer the modern ones. Today, children are often get used to digital games such as video games, Playstation, and online games. These games seem to be modern games because they are played by using modern and sophisticated equipment with the latest technology. They are, of course, far different from traditional games which sometimes do not need any equipment. If there is equipment for the game, it is usually a simple one which is easily found in the surrounding place like stones, twigs, or dry leaves [11]. In addition, computer-based games have the possibility of players cheating to win [12].

Based on the explanation above, the formula of the problems in his research was, what factors which established character building in the traditional game, kasti as local wisdom?

\section{RESEARCH METHOD}

The process [13] of the development and the establishment of a person's character is influenced by two factors: environmental factor and congenital factor. Psychologically, behavior is the realization of potency: Intelligence Quotient (IQ), Emotional Quotient (EQ), Spiritual Quotient (SQ), andAdverse Quotient (AQ) owned by a person. Character configuration in the context of totality in the psychological and socio-cultural process can eventually be grouped in four categories: the process of heart, the process of mind, physical process and kinesthetic, the process of feeling exercise, and the process of volition. The four psycho-social processes are related holistically and coherently to each other and complimentary to each other in order to establish the character as the realization of the sublime values in one's self. The growth and the development of good character will encourage students to grow with their capacity and commitment to do the best and the right things which lead to the goal of life. 
Character does not function in a vacuum space [14]; it functions in the social environment and domain. It is known that moral values and moral feelings clearly have the influence on moral behavior, especially when both of them appear at the same time. However, the influence is overlapping. For example, when one forgives and does the right thing to someone else who is angry, he will usually has good and positive feeling toward that person.

It is said [15] that there are 18 (eighteen) values of character building: (1) religious value: attitude and behavior which show adherence to carry out religious doctrine, being tolerant toward religious rituals done by different religious followers, and live harmoniously with the other religious followers; (2) honesty: an effort to make one's self a person who is credible in any speech, action, and work; (3) tolerance: behavior and action of someone who appreciate other people's religion, ethnicity, opinion, attitude, and action which are different from his (4) discipline: someone's action which indicates orderly and adherence to various regulations and legal provisions; (5) hard working, a behavior which shows seriousness in solving any obstacles in studying and working and carrying out any assignment as well as possible; (6) creativity in thinking about something which yields new things which have been owned; (7) independence: attitude and behavior which do not easily rely on other people in carrying out his tasks; (8) democracy: in the way of thinking, behaving, and acting; one who values his right and obligation equal to other people's; (9) anxiety: behavior and action which always attempt to know more something which he is learning; (10) spirit of nationality, the way of thinking, acting, and having a conception which place national interest rather than vested interest or the interest of one's group; (11) love the country: the way of thinking, behaving, and acting which indicate high loyalty, care, and appreciation to language and physical, social, cultural, economic, and political condition of the nation; (12) appreciating achievement: behavior and action encourage someone to yield something which is beneficial for the people and recognizing and respecting other people's achievement; (13) being friendly, an action which is emphasized on feeling happy to talk, to socialize, and to work together with other people; (14) peace loving: attitude, speech, and action which cause other people to feel happy and safely on one's presence; (15) being fond of reading: a habit of providing spare time to read various kinds of reading materials which give benefit to one's self; (16) caring for environment: attitude and action which always attempt to prevent natural environmental damage in one's surrounding and to improve the damage; (17) social care: attitude and action which always have the feeling of helping other people who need help; (18) responsibility: one's attitude and behavior to carry out his tasks and obligation of what he should do toward himself, the people, and environment (natural, social, and cultural environment) of the country and God Almighty.

In another version, some people categorize character building into 8 (eight) elements of character: (1) honesty, (2) compassion, (3) good judgment, (4) courage, (5) kindness, (6) selfcontrol, (7) cooperation, and (8) diligence of hard work [16].

It is said [1] that character education is attempting to describe important pillars of character by indicating the synergy among home, school, community, and business world. Concerning the synergy above, there are 9 (nine) elements of character: (1) responsibility, (2) respect, (3) fairness, (4) courage, (5) honesty, (6) citizenship, (7) self-disciplined, (8) caring, and (9) perseverance.

In establishing character building, itis necessary if the version above is made as a reference, based on our own cultural local wisdom. To complete the explanation above, based on the perspective of Huitt's behavioral model in his research [17], it is necessary to understand that the development of individual character includes 4 components: cognitive, affective, volition, and behavior. 


\section{RESULT AND DISCUSSION}

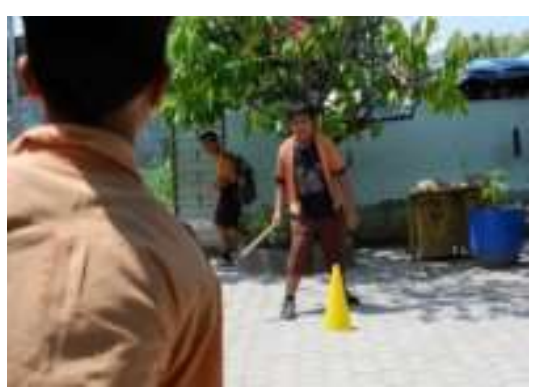

Figure 1. Traditional game kasti.

The name, kasti is not very popular in Indonesia. Even though this game might have the same way of playing, it has different names according to the persons who see it. This game is a traditional game which is mostly played by boys. It is really not known its history; one thing for sure is that it is traditional game of cultural art which has existed from generation to generation inherited by the ancestors. It needs accurate throw and how to avoid speedily.

It is found [18] that kasti has its own rules as follows:

a. This game is played by at least six players;

b. It needs a ball and chalk to make square sections according to the number of players who play the game; in each section is written the name of one player;

c. Players take turn in throwing or rolling the ball; when the ball stops in one section, the player whose name is written on that section will be "a cat";

d. The cat has the job to throw the ball to the other players. If the ball catches one of the other players, he will get the point;

e. If the point has reached a certain limit which has been agreed by all players at the beginning of the game.

Table 1. Analysis on the Data of the Values in Character Building in the Game

\begin{tabular}{|c|c|c|}
\hline No & $\begin{aligned} \text { Playing Technique } \\
\end{aligned}$ & Character Building \\
\hline 1. & $\begin{array}{l}\text { Preparing a ball and chalk to make sections according to the } \\
\text { number of the players and a player's name is written on each } \\
\text { section; }\end{array}$ & Creativity \\
\hline 2. & Reciting prayers before playing; & Religiosity \\
\hline 3. & The rules of the game is explained; & Curiosity \\
\hline 4. & $\begin{array}{l}\text { Players adhere to the order and to various rules and } \\
\text { regulations in the game; }\end{array}$ & Discipline \\
\hline 5. & $\begin{array}{l}\text { Players play in turn to throw and to roll the ball; if the ball } \\
\text { stops in one section, the person whose name is written on the } \\
\text { section will be "a cat"; }\end{array}$ & Democracy \\
\hline 6 & $\begin{array}{l}\text { The game trains players to be focused because routine and } \\
\text { serious exercises are needed to be focused to hit the ball; }\end{array}$ & Hard Working \\
\hline 7. & $\begin{array}{l}\text { "The cat" has the job to throw the ball to the other players, } \\
\text { he will get the point; }\end{array}$ & Tolerance \\
\hline 8 & $\begin{array}{l}\text { When the pint has reached a certain limit, the player will get } \\
\text { punishment which has been agreed at the beginning of the } \\
\text { game; }\end{array}$ & Democracy \\
\hline
\end{tabular}


9. It is not easy to play the game since the players depend on one to another;

10. The player who first reaches the main point will be the winner and get the point;

11 There will be the winners and the losers in the game.
Responsibility

Achievement

Appreciation

Based on the explanation of the data above, it was found that the values of character building in the traditional game, kasti were determined as follows:

a. The traditional game constituted (a) creativity, (b) religiosity, (c) curiosity, discipline, (e) democracy, (f) hard working, (g) tolerance, (h) democracy. (i) responsibility, (j) achievement, (j) appreciation

b. It is necessary to understand the values of character building in the traditional game. Kasti that the development of character building includes establishing cognitive component, knowledge of the character values of the traditional game about good and bad with rational basis which will creatively process moral decision by developing imagination, creativity, problem solving, and skill in children's affective, volitional, and behavioral development. The cognitive knowledge will influence the establishment values of what will be instilled in the affective components to yield morals or ethics of good mentality: to help children communicate their feelings effectively and naturally, decrease their anxiety, maintain their self-control, and train their concentration. These two components will eventually influence the component of volition in the form of commitment to create good and bad psychometric behavior.

As in school, this game consists of critical importance, all payers lead themselves to large "value add" on noncognitive skills, in terms of producing desirable long terms outcome like course taking and graduation as much as other players who are good at adding value to the (much more easily measured) skills. And that means that, at present, we risk failing to find, study, reward, and replicate half of what matters for life success, and can be learned from the game, and other players who are on paths to a life time of success [19] [20].

\section{CONCLUSIONS}

From the result of the analysis above, it could be concluded that the traditional game, kasti integrated Character Building as follows: (a) creativity, (b) religiosity, (c) curiosity, (d) discipline, (e) democracy, (f) hard working, (g) tolerance, (h) responsibility, (i) achievement, and (j) appreciation.

Cognitive aspect in the knowledge of character values in the traditional game, kasti was about good and bad with rational basis which will process creatively moral decision to develop imagination, creativity, and problem solving which develop children's skill in their growth. The cognitive knowledge will eventually influence the values of what establishment which will be instilled in the affective components in order to yield moral and ethical values for good mental health: to help children communicate their feelings effectively and naturally, decrease their anxiety, maintain their self-control, and train their concentration. These two will eventually influence the component of volition in the form of commitment to create good and bad psychometric behavior. 


\section{Acknowledgements}

This research was funded by the University of North Sumatera under a contract for the implementation of University of North Sumatera DRPM Kemristekdikti research for the 2019 budget year.

\section{REFERENCES}

[1] R. Sibarani, Pembentukan Karakter Berbasis Kearifan Lokal. Jakarta: Asosiasi Tradisi Lisan (ATL), 2015.

[2] I. Kurnia and A. Laila, "Exploring the values of the local wisdom of kediri through harinjing and ceker inscription," in SHS Web of Conferences 42 GC-TALE 2017, 2018.

[3] R. Sibarani, Kearifan Lokal, Hakikat, Peran, dan Metode Tradisi Lisan. Jakarta: Asosiasi Tradisi Lisan (ATL), 2012.

[4] A. Mane Kandari, U. Rianse, M. Iswandi, and N. Arafah, "Local Wisdom as Adaptation Strategy in Suboptimal Land Management at Binongko Island, Wakatobi Indonesia," Biosci. Biotechnol. Res. ASIA, vol. 14, no. 1, pp. 129-136, 2017.

[5] W. Hidayati, "Upaya Meningkatkan Kemampuan Kerjasama Melalui Permainan Tradisional Pada Anak Kelompok A TK Aba Ledok I Kulon Progo Tahun Ajaran 2013/2014." Yogyakarta.

[6] S. Dharmamulya, Permainan Tradisional. Purwangan: KEPEL PRESS, 2005.

[7] P. Hijjang et al., "Puyakhabhu: Local Wisdom Values In Environmental Management At Sentani Indigenous Community In Jayapura Regency, Papua,” Int. J. Arts Sci., vol. 11 , no. 1, pp. 59-66, 2018.

[8] A. Kiran and J. Knights, "Traditional Indigenous Games promoting physical activity and cultural connectedness in primary schools - Cluster Randomised Control Trial," Heal. Promot. J. Aust., vol. 21, no. 2, pp. 149-151, 2010.

[9] V. Trajkovik, T. Malinovski, T. Vasileva-Stojanovska, and M. Vasileva, "Traditional games in elementary school: Relationships of student's personality traits, motivation and experience with learning outcomes," PLoS One, vol. 13, no. 8, 2018.

[10] P. Lavega, J. I. Alonso, J. Etxebeste, F. Lagardera, and J. March, "Relationship Between Traditional Games and the Intensity of Emotions Experienced by Participants," Res. $Q$. Exerc. Sport, vol. 85, no. 4, 2014.

[11] N. Haerani, "Membangun Karakter Anak Bangsa Melalui Permainan Anak Tradisional," J. Pendidik. Karakter, vol. 3, no. 1, pp. 87-94, 2013.

[12] A. Antonietti and R. Mellone, "The difference between playing games with and without the computer: A preliminary view," 2003.

[13] A. Wibowo, Manajemen Pendidikan Berkarakter. Yogyakarta: Pustaka Pelajar, 2013.

[14] T. Lickona, Pendidikan Karakter. Bandung: Nusa Media, 2013.

[15] H. Susilo, Nilai Budaya dalam Karya Sastra Daerah Kabupaten Karo Sebagai Bacaan Pembentukan Mental Budaya. Medan: Yayasan Al Hayat, 2018.

[16] A. Releich, Handbook of Character Education. North Carolina: Public School of North Carolina, 2002.

[17] I. Misbach, "Peran Permainan Tradisional yang Bermuatan Edukatif dalam Menyumbang Pembentukan Karakter dan Identitas Bangsa. Laporan Penelitian. Bandung: Universitas Pendidikan Indonesia," 1981.

[18] H. Susilo, "Pemberdayaan Budaya Permainan Tradisional Rakyat di Desa Simpang Mangga Kecamatan Bandar Huluan Kabupaten Simalungun Sebagai Pembentukan 
Karakter Anak Bangsa," Medan, 2018.

[19] A. Sokatch, "Toward a Research Agenda: Building Character Strengths in School Settings," J. Youth Adolesc., vol. 46, no. 6, pp. 1238-1239, 2017.

[20] K. Saddhono, "Language and superdiversity: Indonesians knowledging at home and abroad. By Zane Goebel." Soc. Stu. vol. 12 no.1 pp. 113-118, 2018 